\title{
TREATMENT OF EXPANSIVE SOIL WITH CHEMICAL ADDITIVES
}

\author{
El Sharif M. Abdulaziz ${ }^{1}$, Yahya K. Taha ${ }^{2}$, Mamdouh A. Kenawi ${ }^{3}$ and Ahmed O. Kamel* ${ }^{4}$ \\ ${ }^{1,2}$ Civil Engineering Department, Faculty of Engineering, Assiut University, Assiut, Egypt \\ ${ }^{3,4}$ Civil Engineering Department, Faculty of Engineering, Sohag University, Sohag, Egypt
}

Received 9 July 2013; accepted 21 August 2013

\begin{abstract}
Expansive soil is found in many regions in Egypt, especially in the new desert cities including New Sohag City(town in upper Egypt). In this study, The soil samples were taken from the place of the Faculty of Veterinary Medicine at New Sohag University from a depth of 5 meters and it's used in the experimental program. The physical and mechanical properties of the natural soil were obtained. Then the soil was treated with chemical additives (Addicrete P and Addicrete BV) $0.5 \%, 1 \%$ and 2\% by dry weight of soil. After treatment of soil the properties of the samples were investigated. The natural soil properties were used as control points for comparison purposes.

The main results show that with increase of Addicrete $\mathrm{P}$ the plastic limit increases and liquid limit decreases, hence decreases plasticity index and it is revealed that a change of expansive soil texture takes place when Addicrete P are mixed with expansive soil. While Addicrete BV does not effect on the Atterberg limits or the soil texture of the soil. As the amount of "Addicrete P and Addicrete $\mathrm{BV}$ " is increased, there are an apparent reduction in optimum moisture content ,unconfined compressive strength, free swell, swelling potential and swelling pressure, and a corresponding increase in maximum dry density.

The paper contains many important test results and these results were analyzed to establish optimum dosage levels for each of the treated additives. Based on the results obtained, it can be concluded that the expansive soil can be successfully improved by Addicrete P and Addicrete BV.
\end{abstract}

Keywords: Expansive soil, Swelling soil, Soil Stabilization, Addicrete P, Addicrete BV, clay minerals, swelling potential, swelling pressure.

\section{Introduction}

Expansive soils denote clayey soils that not only possess the tendency to swell or increase in volume but also to shrink or decrease in volume when the prevailing moisture condition is allowed to change. Such change of moisture content of these soils can emanate from rains, floods, or leakage of sewer lines.

The response of expansive soils in the form of swelling and shrinkage due to changes in water content is frequently expressed superficially as heaving and settlement of lightly loaded geotechnical structures such as pavements, railways, roadways, channel and foundations or reservoir linings. Expansive materials that exhibit swelling problems include bentonitic mudstones, marls and silty mudstones, argillaceous lime- stones and altered conglomerates. Consequently, expansive soils cause distress and damage to structures founded on them "Amer[1]".

The climate in Egypt is arid, with high evaporation rates, so that there is always a moisture deficiency in soils and rocks. Supply of water from any source is liable to cause ground heave in any soils or rocks possessing swelling potential. Danger of expansive soils seem to be overlooked during the design and construction of some projects. Problems

* Corresponding author.

Email: engaaa780@yahoo.com 
associated with expansive soils in Egypt are predominantly related to the presence of montmorillonite clay minerals in soils. As a result, some of structures in New Sohag City were subjected to distress and damage and in worst cases some building were demolished.

Extensive studies have been carried out on the stabilization of expansive soils using various additives such as lime, cement, fly ash, industrial waste products and Polypropylene Fiber [2-40]. However, the literature indicates minimal studies on the stabilization of expansive soils in Egypt. Therefore, this study was carried out to add new additives available commercially.

Lime is widely used in civil engineering applications. "Mohamed[2], Basma[3], Sherwood[4], Bell[5], Zhang[6], Amer[7], Arvind[8], Ilknur[9], AlMukhtar[10], Ramesh[11], Jagadish[12], Muzahim[13], Maria[14]" found that when lime is added to clay soils in the presence of water, a number of reactions occur leading to the improvement of soil properties. These reactions include cation exchange, flocculation and carbonation. The cation exchange takes place between the cations associated with the surfaces of the clay particles and calcium cation of the lime. The effect of cation exchange and attraction causes clay particles to become close to each other, forming floc; this process is called flocculation. Flocculation is primarily responsible for the modification of engineering properties of clay soils when treated with lime. Adding of lime significantly reduces the swelling potential, liquid limit, plasticity index and maximum dry density of the soil, and increases its optimum water content.

Cement stabilization is similar to that of lime and produces similar results. Cement stabilization develops from the cementitious links between the calcium silicate and aluminate hydration products and the soil particles. Add cement to clay soil reduces the liquid limit, plasticity index and swelling potential, also it causes increasing the shrinkage limit and shear strength "Sherwood[4], Amer[7], Croft[15], Amer[16]".

Fly ash produced in the combustion of coals exhibits self-cementing characteristics and can be used in a wide range of stabilization applications. Fly ash treatment can effectively reduce the swell potential of highly plastic clays and prevent the swell beneath the smaller foundation pressures. Laboratory test results on these soils indicate that fly ash is effective in improving the texture and plasticity of the fly ash treated soils by reducing the amount of clay size particles, plasticity index and the swell potential "Zhang[6], Amer[7], Arvind[8], Amer[16], Cokca[17], Zalihe[18], Ezekwesili[19], Vinay[20], Mallikarjuna[21], Mir[22]”.

Fiber inclusions cause significant modification and improvement in the engineering behavior of soils. A number of research studies on fiber-reinforced soils have recently been carried out through triaxial tests, unconfined compression tests, CBR tests, direct shear tests, and tensile and flexural strength tests. One of the primary advantages of randomly distributed fibers is the absence of potential planes of weakness that can develop parallel to oriented reinforcement. (Andersland[23] ; Ranjan [23]; Mirzababaei[24]; Abd El Megeed[25]).

Journal of Engineering Sciences, Assiut University, Faculty of Engineering, Vol. 41, No. 5, September, 2013, E-mail address: jes@aun.edu.eg 


\section{Experimental Program}

\section{1. Materials}

\section{1. 1. Natural soil}

Swelling soil was obtained from Faculty of Veterinary Medicine at New Sohag City at a depth of 5 meters. Natural soil was greenish grey, very hard, laminated silty clay with traces of fine sand and calcareous matters. The ground water table was not being found. A test pit was excavated to obtain disturbed samples. Soil samples were transported to the Soil Mechanics Laboratory at Sohag University for preparation and testing. The physical and mechanical properties of the untreated soil are shown in Table 1. The geotechnical tests were performed in accordance with (Egyptian Code of Soil Mechanics and Foundation Design and Construction, 2009) [26]. Based on Casagrande plasticity chart, the soil was classified as a high plasticity inorganic clay $(\mathrm{CVH})$. X ray diffraction analysis of clay minerals showed the presence of montmorillonite (73.7\%), illite (5.3\%) and kaolinite (21\%). Properties of soil showed a plasticity index (39.7\%) and an activity of 0.945 . According to the Van der Merwe [14] classification system, the soil was classified as a high swelling soil.

\section{1. 2. Chemical additives}

Where the clayey expansive soil is the basic component of the Cement and striking similarity in the properties. Therefore, this study was carried out to treated of expansive soils using additives (Addicrete $\mathrm{P}$ and Addicrete BV). Properties of Additives are given in Table 2.

\section{2. Laboratory tests}

The soil was placed in an oven at $105 \mathrm{C} 0$ for $24 \mathrm{hrs}$. The dry soil was pulverized to minus 40 sieve size. Then the soil was mixed with the additives at percentages $0.5 \%, 1 \%$ and $2 \%$ of unit weight of dry soil. Influence of additives on the geotechnical characteristics of expansive soil was investigated by conducting Atterberg Limits, standard Proctor compaction tests, unconfined compression tests, and swelling tests. The details of the tests performed are given in the following sections and the results of these tests are given in Table 3.

\section{2. 1. Atterberg limit tests}

In the laboratory, Casagrande's apparatus has been used to determine liquid limit. The recorded values have been plotted on a semi-log scale and approximated as straight line. The water content corresponding to number of 25 has been considered to be the liquid limit (L.L) for the specific soil category under consideration. The plastic limit has been determined for each soil category. The plastic limit (P.L.) has been calculated as the average of three values of water contents for each soil category. For each soil category the plasticity index has been determined as the difference between the liquid limit and plastic limit. This index together with its liquid limit has been plotted on the A-line chart for each soil category [26].

Journal of Engineering Sciences, Assiut University, Faculty of Engineering, Vol. 41, No. 5, September, 2013, E-mail address: jes@aun.edu.eg 


\section{2. 2. Compaction test}

The test was used to determine the optimum moisture content of the soil corresponding to a maximum dry unit weight condition. For each soil category, five soil samples with different water contents have been prepared and compacted according to the standard compaction test.

Table 1.

Properties of Natural Soil.

\begin{tabular}{|c|c|c|c|}
\hline Properties & Values & Properties & Values \\
\hline Natural water content (\%) & 3.4 & $\mathrm{pH}$ & 8.9 \\
\hline Field dry unit weight $(\mathrm{t} / \mathrm{m} 3)$ & 2.05 & "L.L\%" & 70.7 \\
\hline Specific gravity & 2.69 & "P.L\%" & 31 \\
\hline Passing No. 200 sieve (\%) & 90 & "P.I\%" & 39.7 \\
\hline Clay content $(\leq 2 \mu \mathrm{m})(\%)$ & 42 & "O.M.C \%" & 16 \\
\hline Clay activity & 0.945 & " $\gamma \mathrm{d}_{\max }$ " $\left(\mathrm{t} / \mathrm{m}^{3}\right)$ & 1.522 \\
\hline Unified Soil Classification & $\mathrm{CVH}$ & $\mathrm{UCS}(\mathrm{kg} / \mathrm{cm} 2)$ & 6.035 \\
\hline Montmorillonite $(\%)$ & 73.7 & "F.S\%" & 185 \\
\hline Illite $(\%)$ & 5.3 & Swelling Potential $(\%)$ & 40 \\
\hline Kaolinite $(\%)$ & 21 & Swelling Pressure $(\mathrm{kg} / \mathrm{cm} 2)$ & 3.95 \\
\hline
\end{tabular}

Table 2.

Characteristics of Additives.

\begin{tabular}{|c|c|c|}
\hline Properties & ADDICRETE P & ADDICRETE BV \\
\hline Field Of Use & $\begin{array}{l}\text { Lime Replacer, Mortar } \\
\text { Plasticizer }\end{array}$ & $\begin{array}{l}\text { Water reducing and plasticizer } \\
\text { concrete admixture }\end{array}$ \\
\hline Advantages & $\begin{array}{l}\text { - Entrains a controlled amount } \\
\text { of microscopic air bubbles } \\
\text { which act as frictionless } \\
\text { aggregate in the mortar and } \\
\text { reduces the amount of water } \\
\text { required to give a specific } \\
\text { consistency. } \\
\text { - Permits saving in cement } \\
\text { content and minimize the risk } \\
\text { of cracking and crazing of } \\
\text { plastering. } \\
\text { - Improves moisture retention } \\
\text { and bond properties of the } \\
\text { mortar and minimizes the } \\
\text { risk of separation of } \\
\text { plastering from wall surfaces. } \\
\text { - Produces mortars highly } \\
\text { resistant to disruption caused }\end{array}$ & $\begin{array}{l}\text { - Improves workability, with } \\
\text { easier and quicker placing and } \\
\text { compaction. } \\
\text { - Provides a higher strength } \\
\text { without increase of cement } \\
\text { content or reduction of } \\
\text { workability. } \\
\text { - It improves the quality, the } \\
\text { density and appearance of } \\
\text { concrete, It improves durability } \\
\text { and surface finishes. } \\
\text { - It produces higher cohesion. } \\
\text { Risk of segregation and } \\
\text { bleeding are minimized Without } \\
\text { reduction in the water content, it } \\
\text { increases the slump and } \\
\text { significantly improves concrete- } \\
\text { flow characteristics. }\end{array}$ \\
\hline
\end{tabular}

Journal of Engineering Sciences, Assiut University, Faculty of Engineering, Vol. 41, No. 5, September, 2013,E-mail address: jes@aun.edu.eg 
Ahmed O. Kamel, et al, Treatment of Expansive Soil With Chemical Additives, pp. 1765 - 1777

\begin{tabular}{|c|c|c|}
\hline Properties & ADDICRETE P & ADDICRETE BV \\
\hline Field Of Use & $\begin{array}{c}\text { Lime Replacer, Mortar } \\
\text { Plasticizer }\end{array}$ & $\begin{array}{c}\text { Water reducing and plasticizer } \\
\text { concrete admixture }\end{array}$ \\
\hline & $\begin{array}{c}\text { by ground moisture capillary } \\
\text { action. } \\
\text { • Eliminates use of lime, saving } \\
\text { storage space and plastering } \\
\text { failures due to unsound lime. }\end{array}$ & $\begin{array}{c}\text { Easier low pumping pressures, } \\
\text { which prevent clogging and } \\
\text { reduce friction in the pipeline. } \\
\text { It increases durability and } \\
\text { resistance of concrete to attack } \\
\text { by aggressive agents. }\end{array}$ \\
\hline Appearance & Light brown Liquid & Brown liquid. \\
\hline Density & $1.01 \pm 0.01 \mathrm{~kg} / \mathrm{lit}$. & $1.18 \pm 0.01 \mathrm{~kg} / \mathrm{lit}$. \\
\hline
\end{tabular}

\section{2. 3. Unconfined compressive test}

Unconfined compression test was carried out on soil specimens. The natural and treated soil were compacted at optimum moisture content and maximum dry density at standard compression test. From molds, specimens of $38.1 \mathrm{~mm}$ diameter and $76.2 \mathrm{~mm}$ long were extracted and stored in desiccators at room temperature for curing. Samples were tested after 3 days of curing. The unconfined compressive strength was determined at a loading rate of $1.00 \mathrm{~mm} / \mathrm{min}[26]$.

\section{2. 4. Swelling tests}

\section{2. 4. 1. Free swelling test}

According to the free swell method, an initial volume(Vi) of $10 \mathrm{~cm} 3$ of dry soil passing sieve No.40 has been poured into a $100 \mathrm{~cm} 3$ graduate cylinder filled with water. The volume of the swelled soil (Vf) after 24 hours has been recorded from the graduation of the cylinder. The percentage of free swelling (F.S.) has been calculated as following:

$$
\text { F.S. }=(\mathrm{Vf}-\mathrm{Vi}) / \mathrm{Vi}
$$

\section{2. 4. 2. Pre-swelled swelling test}

The standard oedometer was used to measure swelling potential and swelling pressure. Swelling potential has been used to describe the ability of a soil to swell in terms of volume change, and it is defined as the ratio of increase in height to the original height due to an increase in moisture content. Swelling pressure is designated as the pressure required to return sample to its original volume[26].

\section{Results and analysis}

Results of the standard compaction Proctor tests, Atterberg limits and swelling tests with the natural and with additives states of the clay samples are shown in Table 3.

Journal of Engineering Sciences, Assiut University, Faculty of Engineering, Vol. 41, No. 5, September, 2013, E-mail address: jes@aun.edu.eg 
Table 3.

Properties of natural and treated soil.

\begin{tabular}{|c|c|c|c|c|c|c|c|}
\hline Characteristics & 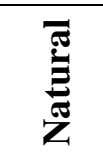 & $\begin{array}{l}a \\
0 \\
10 \\
0 \\
0\end{array}$ & $\begin{array}{l}a \\
\stackrel{\theta}{0} \\
\stackrel{0}{-}\end{array}$ & $\stackrel{\ominus}{i}_{i} a$ & 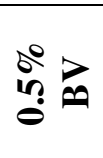 & $\stackrel{\circ}{\ddot{i}}$ & $\stackrel{\stackrel{0}{i}}{\vec{i}}$ \\
\hline "L.L\%" & 70.7 & 64 & 60.7 & 60.5 & 70.5 & 70 & 70 \\
\hline "P.L\%" & 31 & 31.5 & 32.5 & 33.5 & 35.7 & 34.5 & 34.5 \\
\hline "P.I\%" & 39.7 & 32.5 & 28.2 & 27 & 34.8 & 35.5 & 35.5 \\
\hline $\begin{array}{c}\text { Unified Soil } \\
\text { Classification }\end{array}$ & VHC & $\begin{array}{l}\mathrm{CH}- \\
\mathrm{MH}\end{array}$ & MH & MH & $\mathrm{MVH}$ & MVH & MVH \\
\hline$" \gamma d_{\max } "\left(t / m^{3}\right)$ & 1.522 & 1.529 & 1.540 & 1.544 & 1.577 & 1.621 & 1.629 \\
\hline "O.M.C \%" & 16.0 & 14.0 & 13.2 & 12.4 & 15.2 & 14.4 & 13.2 \\
\hline "UCS" (kg/cm2) & 6.035 & 5.048 & 3.651 & 2.872 & 4.149 & 3.050 & 2.703 \\
\hline "F.S\%" & 185 & 150 & 100 & 90 & 165 & 120 & 110 \\
\hline Swelling Potential\% & 40.0 & 36.4 & 21.2 & 18.6 & 35.1 & 18.6 & 18.2 \\
\hline $\begin{array}{l}\text { Swelling Pressure } \\
\left(\mathrm{kg} / \mathrm{cm}^{2}\right)\end{array}$ & 3.95 & 3.71 & 3.55 & 3.55 & 3.55 & 3.39 & 3.31 \\
\hline
\end{tabular}

\section{1. Atterberg limits}

The soil texture, liquid limit, plastic limit and plasticity index of the untreated and treated samples with Addicrete P and Addicrete BV are shown in Figs. 4, 5,6 and 7. The results of the Atterberg limits tests on the soil samples in natural state and when mixed with varying percentages of Addicrete $\mathrm{P}$ show that there is a decrease in both liquid limit and plasticity index and an increase in plastic limit with increasing Addicrete $\mathrm{P}$ content. But for Addicrete $\mathrm{BV}$, there is approximately unchanged in liquid limit, plastic limit or plasticity index.

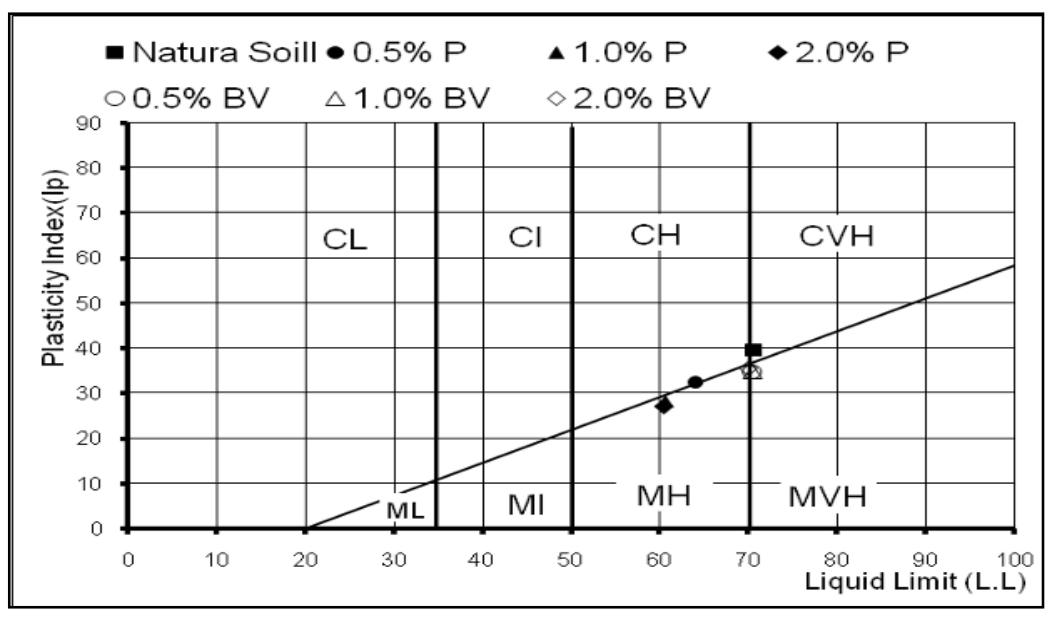

Fig. 4. Effect of additives on soil texture.

Journal of Engineering Sciences, Assiut University, Faculty of Engineering, Vol. 41, No. 5, September, 2013, E-mail address: jes@aun.edu.eg 
Ahmed O. Kamel, et al, Treatment of Expansive Soil With Chemical Additives, pp. 1765 - 1777

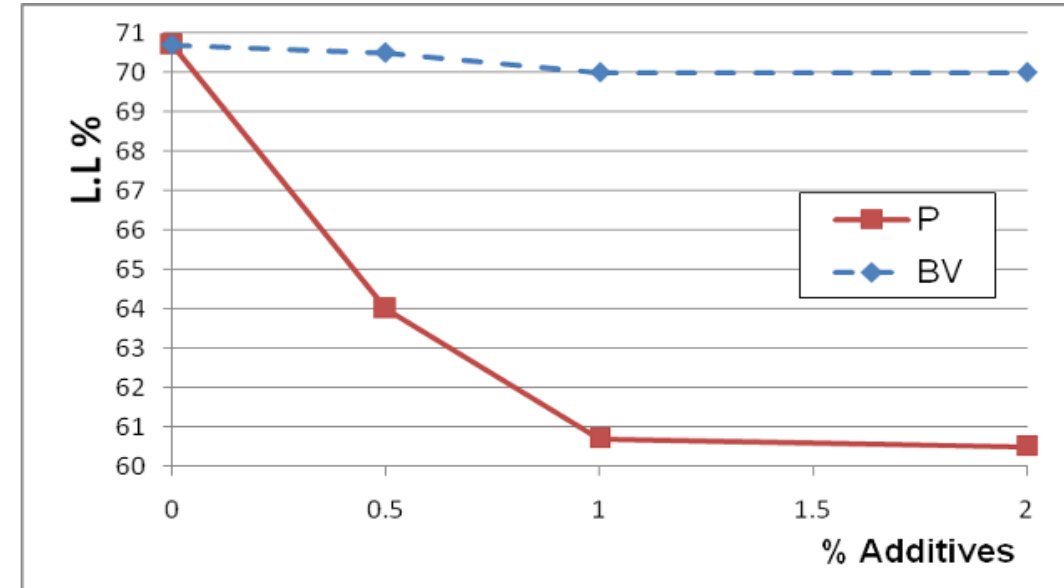

Fig. 5. Effect of additives on liquid limit.

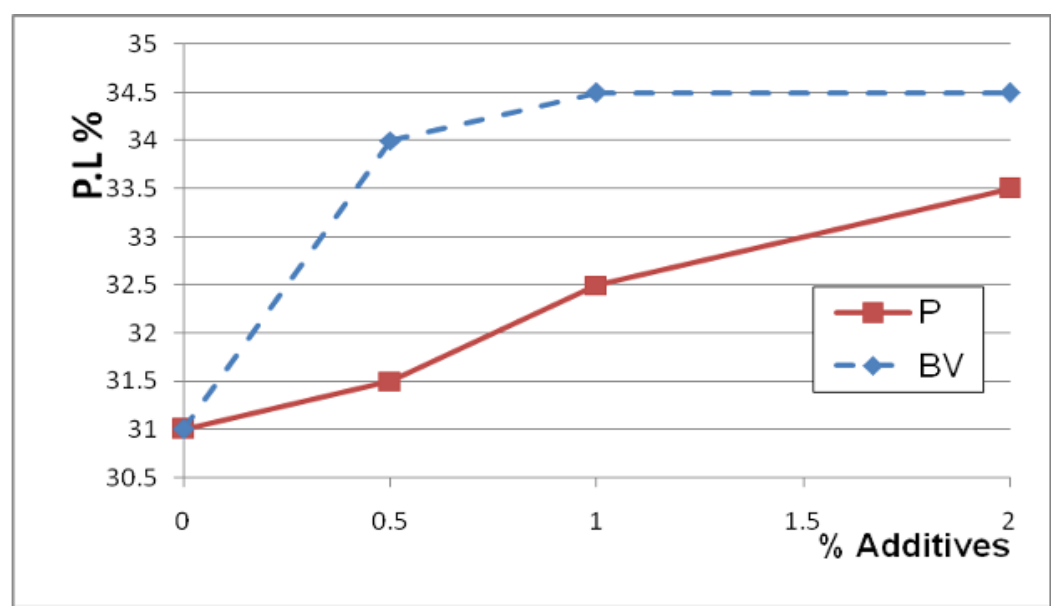

Fig. 6. Effect of additives on plastic limit.

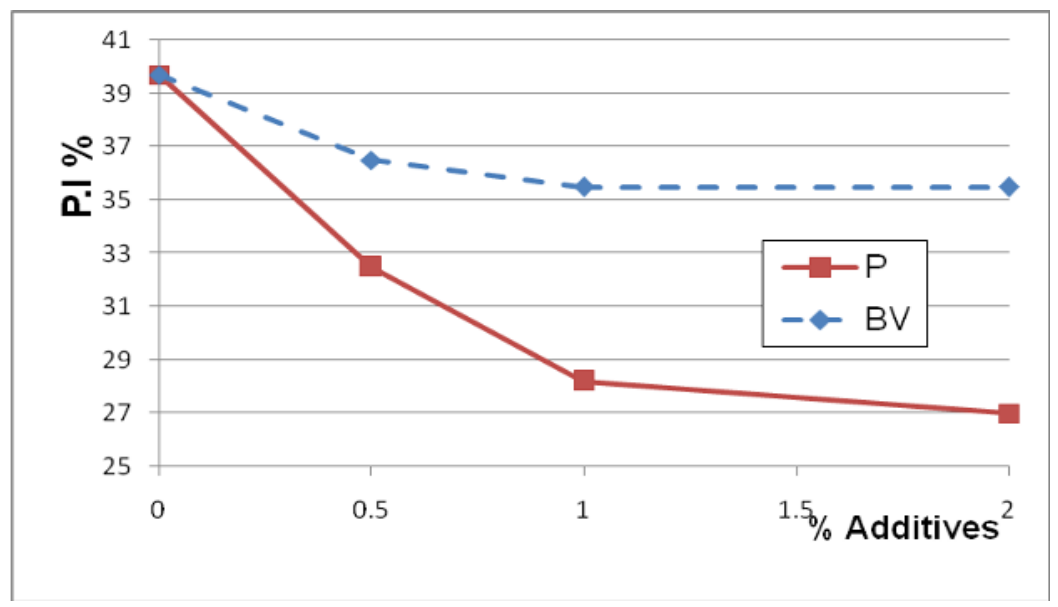

Fig. 7. Effect of additives on plasticity index.

Journal of Engineering Sciences, Assiut University, Faculty of Engineering, Vol. 41, No. 5, September, 2013, E-mail address: jes@aun.edu.eg 


\section{2. Compaction characteristics}

Figs. 8 and Figs. 9 show the relation between maximum dry density and optimum moisture content. From the figures, It is observed that the compaction curve is shifted upward and toward the left with increasing additives. The maximum dry density and optimum moisture content values with different Addicrete P and Addicrete BV contents are illustrated graphically in Figs. 10 and 11. The addition of Addicrete P and Addicrete BV caused an increase in $\gamma \mathrm{d}$ max and a decrease in OMC. The rate of increase in density of soil treated with Addicrete BV is greater than Addicrete P. However, the rate of decrease in optimum moisture content of soil treated with Addicrete $\mathrm{P}$ is greater than Addicrete BV. Also it's found that the rate of increase in density and decrease in optimum moisture content has reduced with increase percentage of additives.

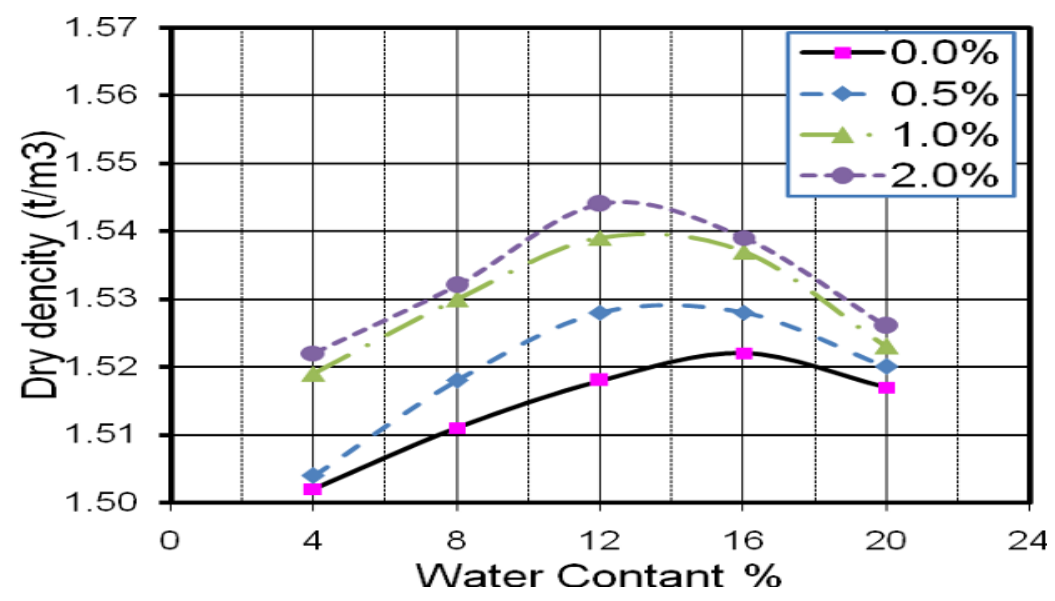

Fig. 8. Effect of Addicrete P on the compaction.

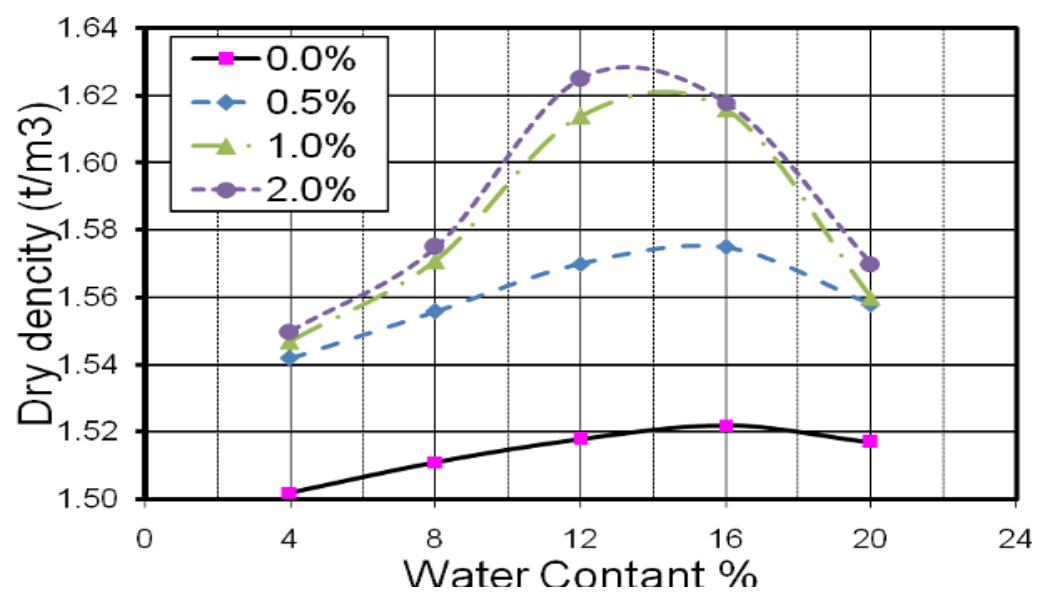

Fig. 9. Effect of Addicrete BVon the compaction.

Journal of Engineering Sciences, Assiut University, Faculty of Engineering, Vol. 41, No. 5, September, 2013, E-mail address: jes@aun.edu.eg 


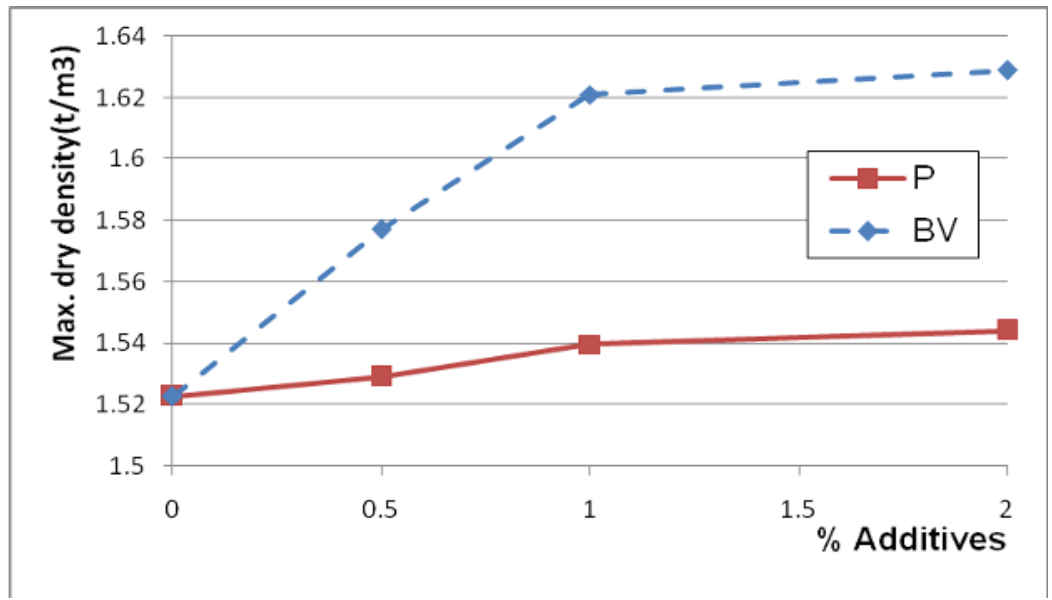

Fig. 10. Effect of additives on max dry density.

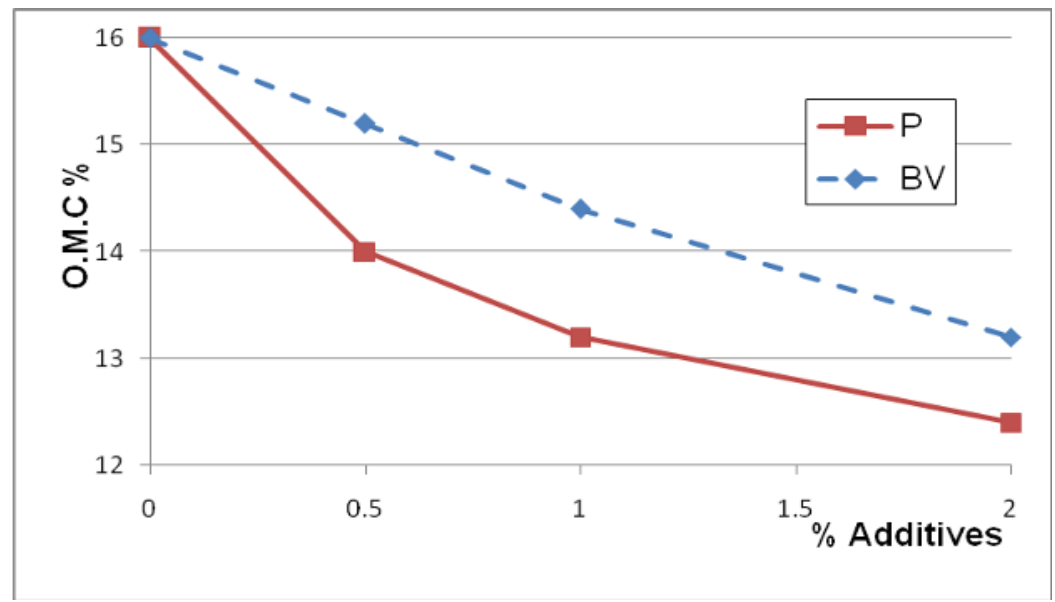

Fig. 11. Effect of additives on optimum water content.

\section{3. Unconfined compressive strength (UCS)}

The relation between unconfined compressive strength and the percentages of additives are illustrated in Fig. 12. From the figure, It can be seen that the unconfined compressive strength of treated soil decrease with increase additives percentage. The rate of reduction in unconfined compressive strength is great up to $1.0 \%$ additive then this reduction is decrease. Also it's found that the reduction of cohesion with using Addicrete BV is greater than the reduction of cohesion with using Addicrete P.

\section{4. Swelling characteristics}

\section{4. 1. Free swelling}

The free swell values for the expansive soil decrease as mixed with additives. The rate of reduction in free swelling is great up to $1.0 \%$ additive then approximately the additive Journal of Engineering Sciences, Assiut University, Faculty of Engineering, Vol. 41, No. 5, September, 2013, E-mail address: jes@aun.edu.eg 
hasn't effect. Also it's found that the rate of reduction of free swelling due to using of Addicrete $\mathrm{P}$ is greater than using of Addicrete BV (as shown in Fig.13).

\section{4. 2. Swelling potential and swelling pressure}

The swelling potential and swelling pressure values for the expansive soil decrease as mixed with additives. The rate of reduction in swelling potential and swelling pressure is great up to $0.5 \%$ additive then the rate of reduction is decrease. Also it's found that the reduction of cohesion due to using of Addicrete $\mathrm{BV}$ is greater than using of Addicrete $\mathrm{P}$ (as shown in Fig.14, 15).

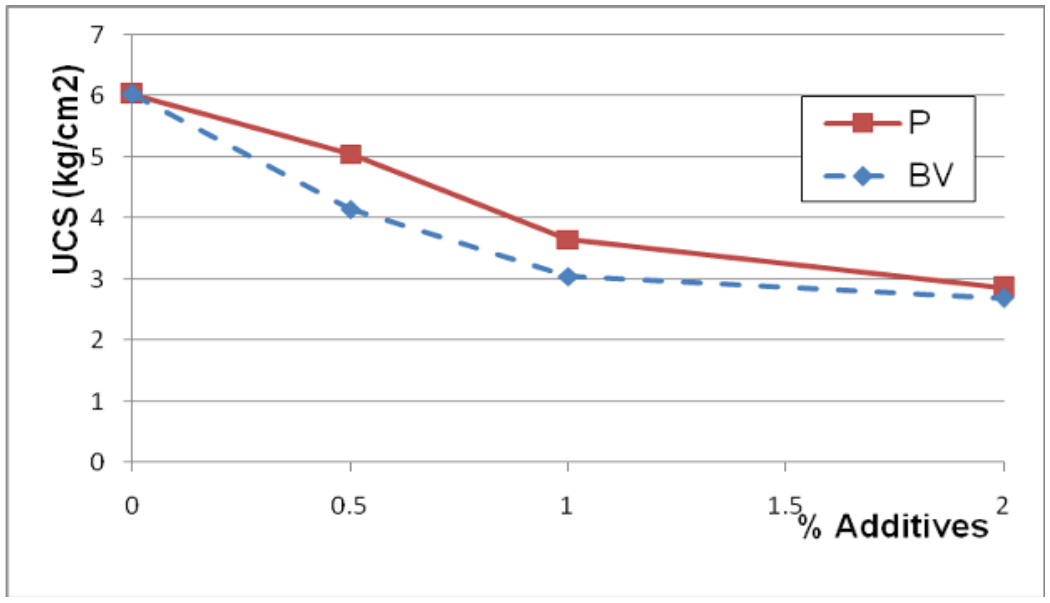

Fig. 12. Effect of additives on unc. comp. strength.

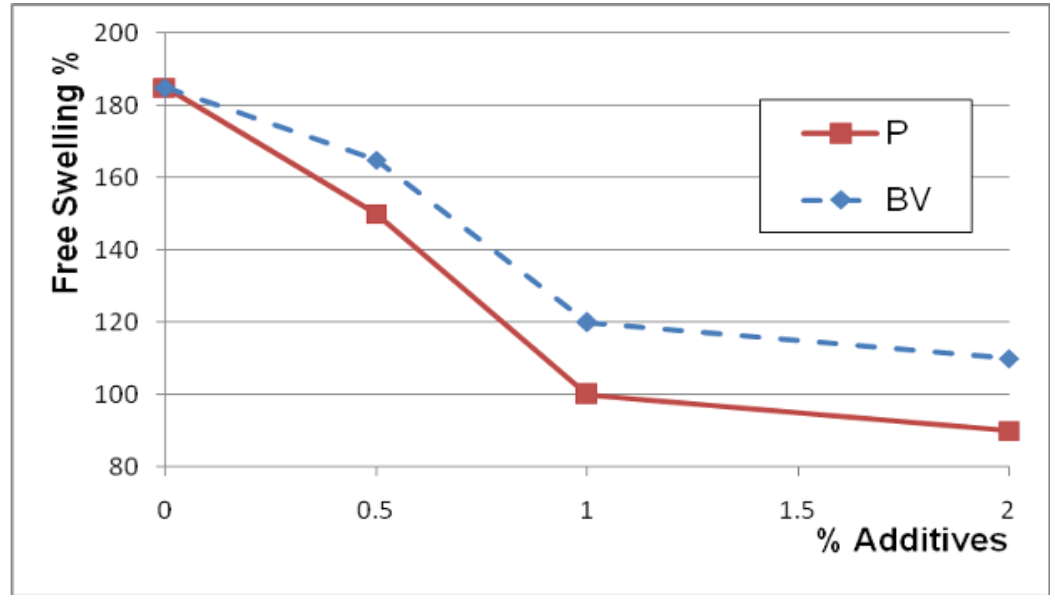

Fig. 13. Effect of additives on free swelling.

Journal of Engineering Sciences, Assiut University, Faculty of Engineering, Vol. 41, No. 5, September, 2013, E-mail address: jes@aun.edu.eg 


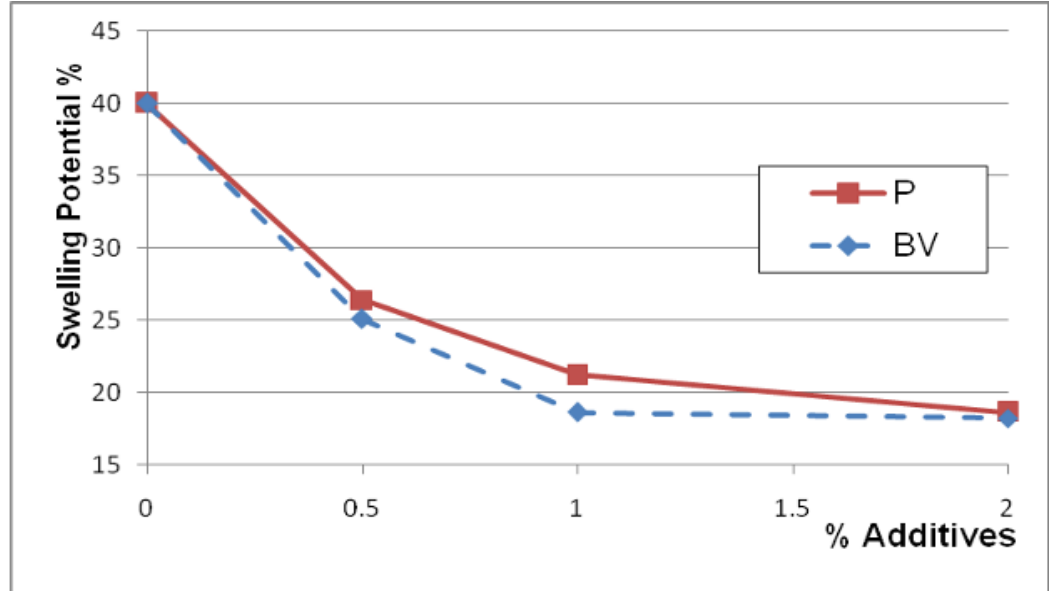

Fig. 14. Effect of additives on swelling potential

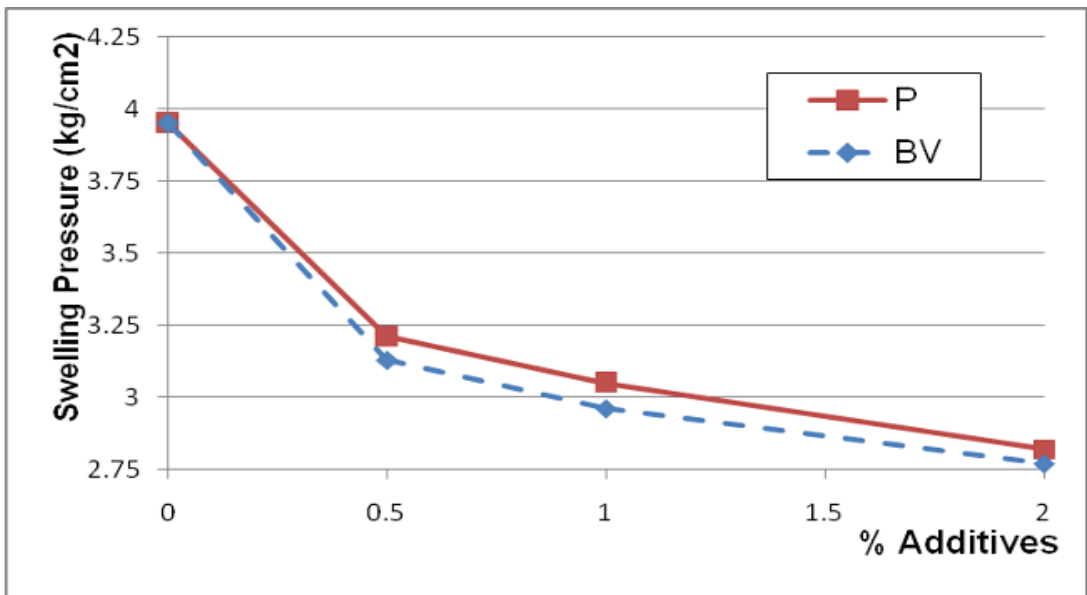

Fig. 15. Effect of additives on swelling pressure.

\section{Conclusions}

Based on the test results and the above analysis, It can be concluded that:

1. The liquid limit and plasticity index of expansive soil decrease, and the plastic limit of expansive soil increases with increase rate of Addicrete P. However, there is approximately no change in liquid limit, plastic limit and plasticity index when adding Addicrete $\mathrm{BV}$.

2. An increase in $\gamma_{\mathrm{d} \max }$ and a decrease in O.M.C. can be happened on expansive soil with adding of Addicrete $\mathrm{P}$ and Addicrete BV. Note that adding Addicrete BV is more effective to increase the density of soil than adding Addicrete P. On the other hand, adding Addicrete $\mathrm{P}$ is more effective in decreasing optimum moisture content of soil than adding Addicrete BV.

Journal of Engineering Sciences, Assiut University, Faculty of Engineering, Vol. 41, No. 5, September, 2013, E-mail address: jes@aun.edu.eg 
3. The rate of unconfined compressive strength of soil decreases with increasing in additives percentage up to $1 \%$ additive, then this reduction is decreases.

4. Swelling values (free swelling, swelling potential and swelling pressure) of the expansive soil decrease when the soil is treated with additives. The rate of decrease is great up to $0.5 \%$ additives, then the reduction approximately be constant.

5. From the results of the present study, Addicrete P and Addicrete BV can be used to be a good stabilizers of expansive clay soil.

\section{Notation}

$\mathrm{pH}=$ power of hydrogen, L.L.= liquid limit, P.L.= plastic limit, P.I. = plasticity index, $\gamma \mathrm{d}$ $\max =$ maximum dry density, O.M.C.=optimum moisture content, UCS=unconfined compressive strength, $\mathrm{C}=$ cohesion, F.S.=free swelling.

\section{References}

[1] Amer A. A., Mattheus F.A.G.(2006) “"Expansive Soils Recent advances in characterization and treatment”. Proceedings and Monographs in Engineering, Water and Earth Sciences, 16.

[2] Mohamed M. El Sherif (1978): "Effect of additive materials on the characteristics of swelling clays". Assuit University, Faculty of Engineering, Civil Engineering aboratory. No. 58, p. $173-177$.

[3] Basma A.A., Tuncer E.R.(1991): "Effect of lime on volume change and compressibility of expansive clays". Transportation Research Board, Washington DC, TRR No. 1296, p. 5461.

[4] Sherwood P.T. (1993). "Soil stabilization with cement and lime". state-of the- art review. Transport Research Laboratory, London: Her Majesty's Stationery Office, 67, 54-61.

[5] Bell F.G.(1996)."Lime stabilization of clay minerals and soils".Engineering Geology,42,223-237.

[6] Zhang J. and Cao X.(2002) "Stabilization of Expansive soil by Lime and Fly Ash". JOURNAL OF WUHAN UNIVERSITY OF TECHNOLOGY, 50(2), 191-198.

[7] Amer A. A., A.W. Hago, Hilal A.(2005). "Effect of lime, cement and Sarooj on the swelling potential of an expansive soil from Oman". Building and Environment, 40 , 681-687.

[8] Arvind K., Baljit S. W. and Asheet B.j(2007). "Influence of Fly Ash, Lime, and Polyester Fibers on Compaction and Strength Properties of Expansive Soil". JOURNAL OF MATERIALS IN CIVIL ENGINEERING, 1561, 242-248.

[9] Ilknur B. , Sanan G. (2010) . "Effects of soil pulverization quality on lime stabilization of an expansive clay". Environ Earth Sci 60,1137-1151.

[10] Al-Mukhtar M., Abdelmadjid L., Jean-Francois A.(2010).“ Behaviour and mineralogy changes in lime-treated expansive soil at $20^{\circ} \mathrm{C}$ ". Applied Clay Science, 17(4), 73-75.

[11] Ramesh H.N. and Mamatha H.V.(2010) " Compaction and strength behavior of lime-coir fiber treated Black Cotton soil”. Applied Clay Science, 17(4), 73-75.

[12] Jagadish P. S.and Pradip K. P.(2010) ."Effect of Lime Stabilized Soil Cushion on Strength Behaviour of Expansive Soil”. Geotech Geol Eng, 1007/S, 153-161.

[13] Muzahim Al-M., Suhail K, Jean-Francois A.(2012) “ Microstructure and geotechnical properties of lime-treated expansive clayey soil”. Engineering Geology 139-140,17-27.

[14] Maria M., Xiwei Z., Michael J. G., Zeljko C.(2013) ."Water Retention and Compressibility of a Lime-Treated, High Plasticity Clay”. Geotech Geol Eng, DOI 10.1007/s10706-0139642-6.

Journal of Engineering Sciences, Assiut University, Faculty of Engineering, Vol. 41, No. 5, September, 2013, E-mail address: jes@aun.edu.eg 
[15] Croft JB.(1967), "The influence of soil mineralogical composition on cement stabilization". Geotechnique, vol. 17, London, England, p. 119-135.

[16] Amer A. A.(2002), "Microfabric and mineralogical studies on the stabilization of an expansive soil using cement bypass dust and some types of slags". Can. Geotech, vol. 39, $1150-1169$.

[17] Cokca, E.(2001). "Use of Class C fly ashes for the stabilization of an expansive soil." J. Geotech. Geoenviron. Eng., 127 (7), 568-573.

[18] Zalihe Nalbantoglu. "Effectiveness of Class C fly ash as an expansive soil stabilizer". Construction and Building Materials (2004), 18 377-381.

[19] Ezekwesili Ene, Celestine Okagbue. (2009) "Some basic geotechnical properties of expansive soil modified using pyroclastic dust". Engineering Geology;107:61-65.

[20] Vinay A., Mohit G. (2011). “Expansive Soil Stabilization Using Marble Dust.” International Journal of Earth Sciences and Engineering, Vol. 04, 59-62.

[21] Mallikarjuna K. R., Rama G. V. (2011). "Optimum fly ash for mechanical stabilization of expansive soils using 22 factorial experimental design" Nat Hazards, Vol. 60,703-713.

[22] Mir B. A., Sridharan A. (2013). "Physical and Compaction Behaviour of Clay Soil-Fly Ash Mixtures" Geotech Geol Eng, DOI 10.1007/s10706-013-9632-8.

[23] Ranjan, G., Singh, B., and Charan, H. D. (1999). "Experimental study of soft clay reinforced with sand-fiber core." Indian Geotechnical J., 29(4), 281-291.

[24] Mirzababaei M., Miraftab M., Mohamed M., McMahon P. (2013). "Impact of Carpet Waste Fibre Addition on Swelling Properties of Compacted Clays". Geotech Geol Eng, 31,173-182.

[25] Abd El Megeed Kabasy Mohamed (2013). "Improvement of swelling clay properties using hay fibers". Construction and Building Materials, 38,242-247.

[26] Egyptian Code of Soil Mechanics and Foundation Design and Construction(2009), ECP 202/2-2001. Laboratory tests. Cairo: National Center for Housing and Construction Research.

\section{معالجة التربة الانتفاخية بإضافات كيميائية}

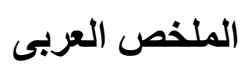

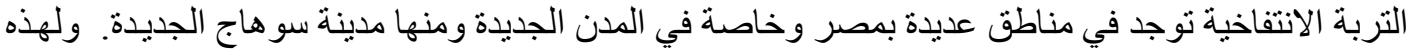

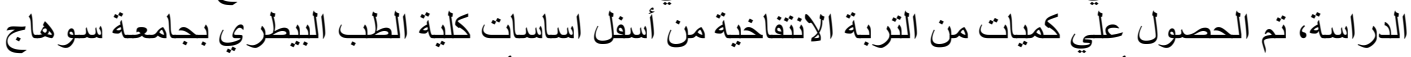

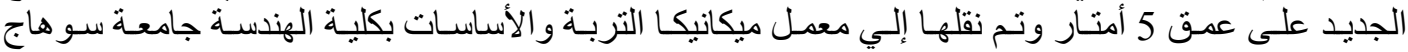

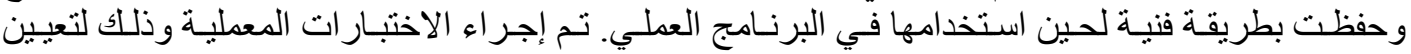

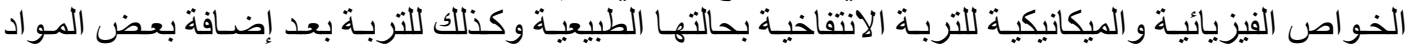
الكيميائية وهي أديكريت بي و أديكريت بي في عند نسب

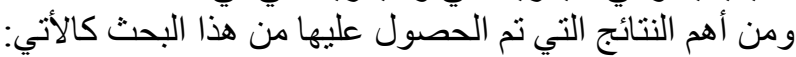

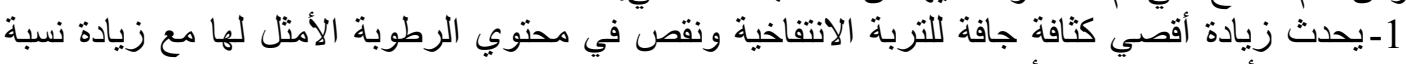

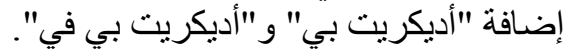

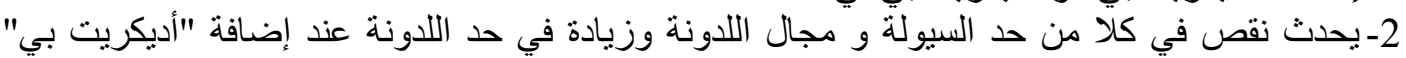

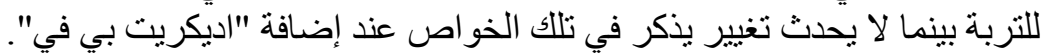

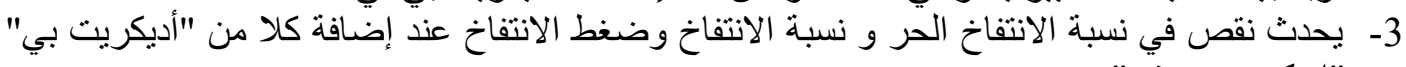

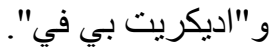
4- يقل قيمة الضغط ألعير محاط للتربة مع زيكية ليادة نسبة المو اد المضافة سواء أديكريت بي أو أديكريت بي في.

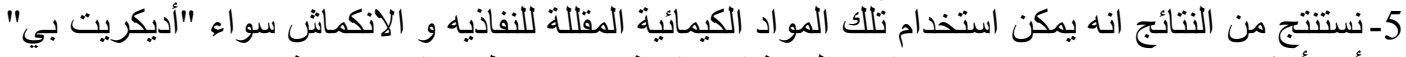

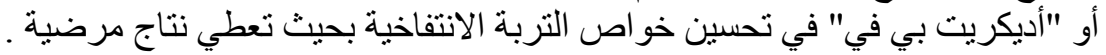

Journal of Engineering Sciences, Assiut University, Faculty of Engineering, Vol. 41, No. 5, September, 2013, E-mail address: jes@aun.edu.eg 